\title{
Species Diversity and Use of Homegardens in Misha Woreda, Hadiya Zone of the Southern Nations, Nationalities and Peoples Regional State, Ethiopia
}

\author{
Girma Woldemichael $^{1}$, Meseret Chimdessa ${ }^{2}$, Anteneh Abebe ${ }^{1}$ \\ ${ }^{1}$ School of Natural Resource Management and Environmental Science, Haramaya University, Ethiopia \\ ${ }^{2}$ School of Biology and Biotechnology, Haramaya University, Ethiopia
}

\begin{abstract}
How to cite this paper: Woldemichael, G., Chimdessa, M., \& Abebe, A. (2018) Species Diversity and Use of Homegardens in Misha Woreda, Hadiya Zone of the Southern Nations, Nationalities and Peoples Regional State, Ethiopia. International Journal of Food Science and Agriculture, 2(7), 118-129.

DOI: $10.26855 /$ ijfsa.2018.12.001
\end{abstract}

*Corresponding author: Girma Woldemichael, School of Natural Resource Management and Environmental Science, Haramaya University, Ethiopia.

Email: girmawolde886@gmail.com

Tell: +251916717815

\begin{abstract}
Homegarden is an intensive land use system involving the deliberate management of multipurpose trees and shrubs grown in intimate association with herbaceous species with diverse use value. The aim of this study was to assess species diversity and use of plant species in the homegardens including their seasonal variation. Four kebeles with distinct altitude were selected purposively, and fifteen homegardens were randomly selected for data collection from each kebele. The survey revealed that people of the study area use homgarden of size ranging from 0.1 to 1 hectare to cultivate plants of different use values. Overall, 62 plant species distributed in to 55 genera and 35 families were recorded in the study area. Habit wise, herbs had the highest number of species (34) followed by trees (15) and shrubs (9). Family Poaceae had the highest number of species (9) followed by Brassicaceae and Rutaceae with eight species in common, and Alliaceae and Lamiaceae with six species in common. Homegarden plant species were categorized in to seven main use categories. Comparison of species richness and diversity between Altitude and Season revealed that altitudinal and seasonal variation had significant effect on species richness and diversity. Although the local people of the study area seem to have culture of maintaining homegardens, they should be aware of diversifying plant species to maximize the use of homegardens.
\end{abstract}

\section{Keywords}

Enset ventricosum; Homegarden; Seasonal variation; Species diversity; use value

\section{Introduction}

The large percentages of our country, Ethiopian population (80\%) depend upon agriculture activities for their livelihoods, and contribute $42-45 \%$ of the total gross domestic product of the country [1]. But, currently, the agricultural production falls under a risk due to a number of factors. Among these; climate change, land degradation in the form of soil erosion, soil fertility loss (which are important for grain yield production) and severe soil moisture stress, which is partly the result of loss of trees in their field and organic matter [2]. Regarding climate change, the country is one of world's drought prone countries, which leads to challenges especially in food production as $95 \%$ of the agricultural activity is dependent on rainfall [3]. Rainfall variability and associated drought have been the major cause of food shortage and famine in Ethiopia [2]. The whole effect of the above problems is loss of biodiversity, financial and food insecurity, malnutrition. These are the major tribulations of human wellbeing that require means to adapt [4].

One means of overcoming the above mentioned problems is through the application of homegarden agroforestry, which can support diverse species than mono-cropping [5]. Homegarden is an intensive land use system involving the deliberate management of multipurpose trees and shrubs (the woody component) grown in intimate association with herbaceous species (mainly annual, perennial, and seasonal agricultural crops) where livestock management is an integral part within the compounds of individual homes [6-8]. 
The high diversity of species in homegarden have a wide socioeconomic and ecological roles including production of food and a wide range of other products such as firewood, fodders, spices, medicinal plants and ornamentals [9] and avoidance of environmental deterioration of climate related hazards commonly associated with mono-culture production systems[10] income generating site [11].

The diversity of plants in the home garden associated with other organisms contribute to the formation and maintenance of soil structure, retention of moisture and nutrient levels and promotes the recycling of nutrients; which reduces ecosystem vulnerability to climate change [12].

In the enset-based homegarden of south and southwestern part of Ethiopia, enset is the dominant crop [13]. It is a multipurpose crop and nearly every part of the plant has some sort of uses [14]. Enset has ecological and socioeconomic roles such as food for over $20 \%$ of the population living in the southern and southwestern parts of Ethiopian [15] medicine (cure bone fractures, birth problems and diarrhea in human [13], production of construction materials, fodder, increase soil fertility, tolerate climate change and resist drought. Maintenance of diversity through homegarden helps to curb environmental, ecological and socio-economical problems. Though there were some studies conducted in enset based homegardens of some districts in the Southern part of Ethiopia, none has been conducted in Misha District of Hadiya zone, which has got its own ethnobotanical background. This research was therefore, designed to investigate the extent of use of home garden in Misha District with the general objectives to assess species diversity and use of homegardens and specific objectives to identify and document species composition of homegardens, to determine use and diversity of species of homegardens and determine species diversity variation with season and altitude in Misha District.

\section{Materials and Methods}

\subsection{Description of the Study Area}

This study was conducted in Misha district, which is found in Hadiya administrative zone of the Southern Nations Nationalities and Peoples Regional (SNNPR) State of Ethiopia. The district is located at a distance of $250 \mathrm{~km}$ from Addis Ababa (capital city of Ethiopia) and $18 \mathrm{~km}$ from Hosanna town. The geographic location of the district is at $7^{\circ} 08^{\prime} \mathrm{N}$ latitude and $37^{\circ} 81^{\prime} \mathrm{E}$ longitude. It is bounded with Gurage zone in North and East where as Gibe and Lemmo woredas of Hadiya zone from West and South respectively. The total population of the district is 187521 and the total area of the district covers approximately $304.07 \mathrm{~km} 2$ with an average population density of about 252 household per kilometer square. Therefore Misha district is one of the densely populated areas in the country [16].

The land feature of Misha district is characterized by sloppy and flat however the district is characterized by humid tropical climate. The mean annual maximum and minimum temperatures of the district are $240 \mathrm{C}$ and $130 \mathrm{C}$ respectively. About 70 percent of the land of Misha district lies in the weyena dega (mid altitude between 1500 and 2500 masl), 20 percent of the district lies in the dega (high altitude above 2500 masl) and 10 percent lies in kola (low altitude below 1500 masl) agro-climatic zones [17].

The average annual rainfall of the area ranges from 1500 - $1800 \mathrm{~mm}$ with considerable annual and inter-seasonal variation. The rainfall pattern is bi-modal with short rain season that extends from March to May and long rain season between June and September. The dominant soil type of the area is vertisol [17]. Agricultural activity is the main means of livelihood for the majority of Misha district population. People of the study area use and classify land through functional categorization i.e. grazing land, agricultural land, homegarden land and forestland.

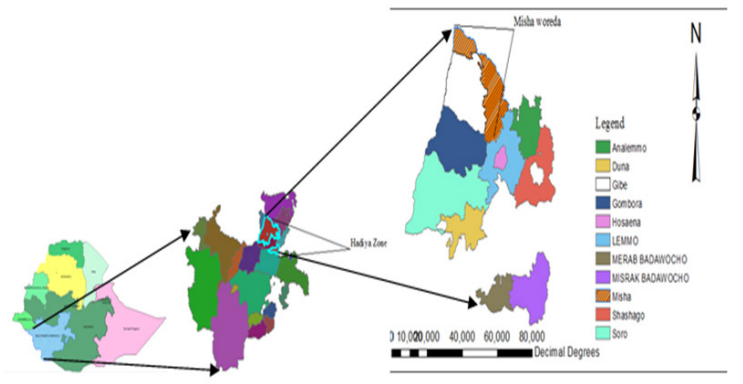

Figure 1. Location of the study area

\subsection{Data Collection}

Misha district has 35 kebele Admintratives (KA). Some of the KA that are found in lower altitudes of $<1500 \mathrm{~m}$ asl do not have homegarden practice. A total of four kebeles were purposively selected for data collection based on homegardening tradition with clear altitudinal differences. Kebele administrative were selected from the two agro-climatic zones, i.e., one KA from daga (above $2500 \mathrm{~m}$ asl), three KA from woynadega (between 2500 and $1500 \mathrm{~m}$ asl). From each kebele, 15 homegardens totaling 60 
homegardens were selected randomly. Thereafter, all the selected homegardens were visited in two seasons, i.e., rainy (JuneSeptember, 2016) and dry (December, 2016-February, 2017) season for data collection.

Sampling from different altitudes and at different seasons helps to understand how species composition and diversity vary with space and time. To sample plant species, two diagonal transects that intersect at about middle of the homegarden were laid starting from closer to the home to the end of the garden so as to cut across all sorts of plant species. Moreover, one transect that vertically cuts through point of intersection of the two transects were laid starting from closer to the house to the end of the garden. Thereafter, sample plots of $10 \mathrm{~m}$ x $10 \mathrm{~m}$ were laid systematically along transects and identity of woody plant species (local name and scientific name when possible) and number of woody plants were recorded from each plot. To sample herbaceous species, 5 small plots $(2 \mathrm{~m} \times 2 \mathrm{~m})$ one from each corner and one from the center of the big plot were laid and the identity of the species with their number was recorded.

In each homegarden, use value of plants encountered, habit, their position relative to the home, and cultivation management was also being obtained. The information of use value and cultivation management of every plant was gathered from mother or father who is the head of household that available in the house during homegardens tour. Voucher specimens of all encountered plants were collected, pressed to dry and identified using relevant literatures and confirmed by experts at Haramaya University Herbarium. Data collection instruments included semi-structured interview of homegarden owners and field observation. Sixty homegarden owners were participated in the semi-structured interview to gather information about size of the homegardens, cultivation management and use value of the encountered plants in the first data collection season in Augest-2016.

\subsection{Data Analysis}

Species richness, diversity, evenness, frequency, and density were first computed. Species richness was determined from the total number of species recorded in sample plots. The diversity of species was analyzed by using the Shannon-Wiener Diversity Index [18]. The index takes into account the species richness and proportion of each species in all sampled quadrats of the study site.

Density of the species was calculated by converting the total number of individuals of each species ' encountered in all the quadrats and all transects used in the site to equivalent number per hectare. The frequency was calculated as the proportion (\%) of the number of quadrats in which each species was recorded from the total number of quadrats in the site.

All measured values were then subjected to the analysis of variance (one-way ANOVA) to compare between the different kebeles so as to reveal the presence of difference in diversity, species richness, density and frequency of species due to altitude. Independent-sample T-test was used to check variation in species diversity and richness between seasons. P-value $<0.05$ was considered as statistically significant value.

\section{Results and Discusion}

\subsection{Homegardening Practice in Misha District}

In this study, of the 60 houses surveyed all had homegardens of size ranging from 0.1-1 hectare (Table 1). Of the surveyed households, $75 \%$ of homegardens were found to be the back yard (dubo, the local name of back yard in hadiya language, hadiyissa). Similarly, it is [19] reported that backyard is the predominant size of homegarden in Dawro and the studied results from 111 homegardens agroforestry of Ethiopia from different agro-ecological zone, confirms that most of the homegardens were positioned in the backyard of an individual house [20] and Fentahun [21] also found this reality from western Amhara of Ethiopia. The remaining 20\% and 5\% were belongs to be as side yards and front yards respectively. Most of the people that found in the study area had larger wheat, barley, bean and pea crop fields than homegarden. Most of the small farm holders use the products of homegardens for home consumption, where as the product obtained from farm field for instance wheat, barley and pea are used to sell for income generation.

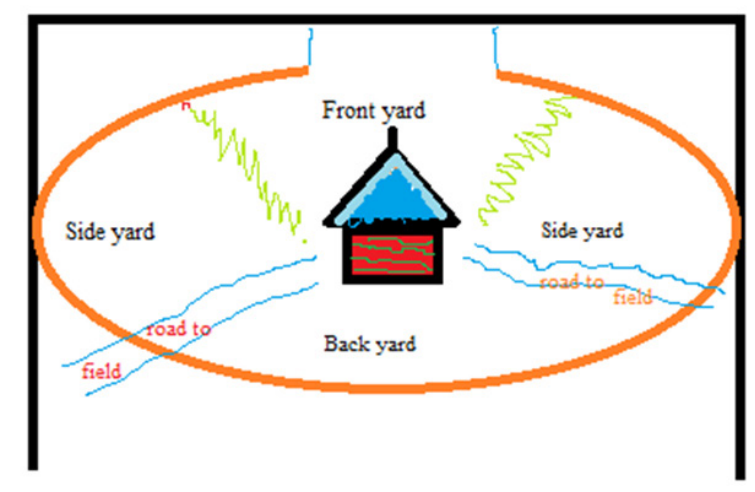

Figure 2. Diagrammatic representation of homegarden in Misha district 
Traditionally, people of Misha district allocate different parts of their compound for different types of plants meant for particular purpose. For example, the front yard (ullumma, local name of front yard), which refers to the portion of the compound found in front of the house is used for growing trees having values for shade, cultural events and used for fuel (Figure 2). This portion had small open space left as play field for children. Since for easy movement of livestock, social and cultural functions, front yard is open with some trees such as Olea europea ssp. cuspidata, Podocarpus falcatus, Cordia africana and Ficus vasta are grown in front yard. According to the respondents, these trees provide shade and serve as places where cultural ceremonies and social gatherings will be held during religious holidays. Similar result was reported from homegardening practice of Wolayta, Ethiopia by Talemos et al. [22] that trees having social and cultural value were planted in Kare'a (front part of homegardens).

Side yards are components of the compound or homegarden closer to the house in opposite sides where spice and medicinal plants are grown. In this study, plants such as Carica papaya, Ocimum lamiifolium, Ruta chalepensis, Allium sativum, Allium cepa, Beta vulgaris, Brassica oleracea, Cucurbita pepo, Daucus carota, Mangifera indica, Coffea arabica, Catha edulis, Citrus sinensis, Phaseolus vulgaris and Collocasia esculenta are most commonly grown in both sides of the house. The reasons to restrict vegetables and spices only near to the house in opposite sides around the living home in the studied homegardens in Misha district are: to give special treatment like manuring and occasional watering (using waste water). Additionally, to save labor of walking towards the end and manages even simultaneously while performing indoor activity like food cooking or theft is fear to come near to the house, farmers cultivate higher number of species near to their house.

On the other hand, Enset ventricosum, Brassica carinata, Zea mays and Percea americana are the prominent plant species in the back yard, the crops like E.ventricosum, C.arabica and B.carinata are well natured from animal urine and droppings flowing into the garden but E.ventricosum dominates the middle of the homegarden. It occupies the largest portion of homegarden because it is the sources of staple food for the studied district. Some fruit trees such as P.americana scatterly grown with the association of enset. The traditional reasons of allocating homegarden at the back side of the home is to take urine and fresh dung out of the house to the homegarden easily, to make it secret and not observable to the other people and to manage easily. Even though, any person cannot across their homegarden without the permission of the homegarden owners. Similarly, Talemos et.al [22] reported that people of Wolayta allocate their homegarden at the back side of their house to open a channel in the ground to take urine and soft dung out of the house to their homegarden.

Table 1. Position and size of homegarden in the study area

\begin{tabular}{|l|l|l|l|l|l|l|l|l|}
\hline Kebeles & \multicolumn{2}{|l|}{$\begin{array}{l}\text { No of house } \\
\text { holds }\end{array}$} & \multicolumn{3}{l|}{$\begin{array}{l}\text { Position of homegarden in relation to } \\
\text { house }\end{array}$} & \multicolumn{3}{l|}{ Size of homegarden in hectare } \\
\hline & & Back yard & Side yards & Front yard & 0.1 & $0.2-0.4$ & 0.5 & 1 \\
\hline Tinika & 15 & 14 & 1 & 0 & 2 & 4 & 8 & 1 \\
\hline Gidasha & 15 & 10 & 4 & 1 & 1 & 1 & 12 & 1 \\
\hline Ololicho & 15 & 13 & 2 & 0 & 3 & 2 & 8 & 2 \\
\hline Forkose & 15 & 8 & 5 & 2 & 4 & 1 & 7 & 3 \\
\hline Total & 60 & 45 & 12 & 3 & 10 & 8 & 35 & 8 \\
\hline$\%$ & 100 & 75 & 20 & 5 & 16.6 & 13.3 & 58.3 & 11.7 \\
\hline
\end{tabular}

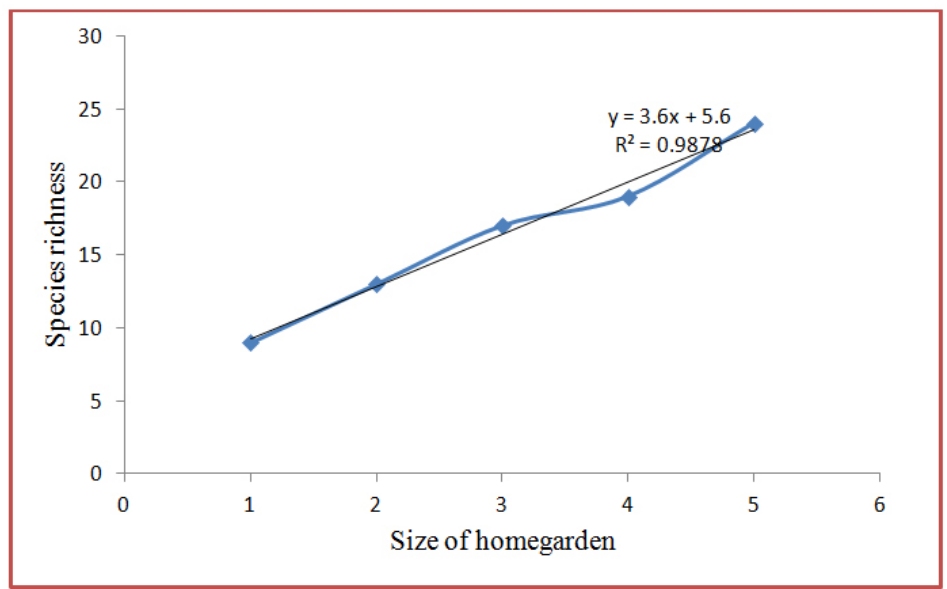

Figure 3. The relationship between homegarden size and species richness 
The size of the homegardens ranged from 0.1 to 1 hectare with different cultivated plants species. Out of the sixty surveyed homegardens, approximately $60 \%$ were found to be size of 0.5 hectare. It is the dominant size of homegarden in the study area. Moreover the size of homegarden is decreasing with increasing population number and decreasing with landholding size. The diversity of species increase with the increase of the size of the homegardens (Figure 3). With increasing of homegarden in holding size, more variations in species composition were encountered. Similarly, Tesfaye [23] reported as the size of homegarden increases, so the diversity of plant species increases in homegarden agroforestry system of southern Ethiopia.

\subsection{Homegarden Plant Species of the Misha District}

In this study, a total of 62 plant species distributed in to 55 genera and 35 families were recorded (Table 2). Poacae had the highest number of species (9) followed by Brassicaceae and Rutaceae with (8) species in common, Alliaceae and Lamiaceae with (6) species in common and 39 species were distributed among the remaining 30 families (Figure 4). A similar report from Wolayta [22] indicated that Fabaceae and Poaceae are the two dominant families in terms of species number, suggesting that people of this region may prefer species of these families for various purposes.

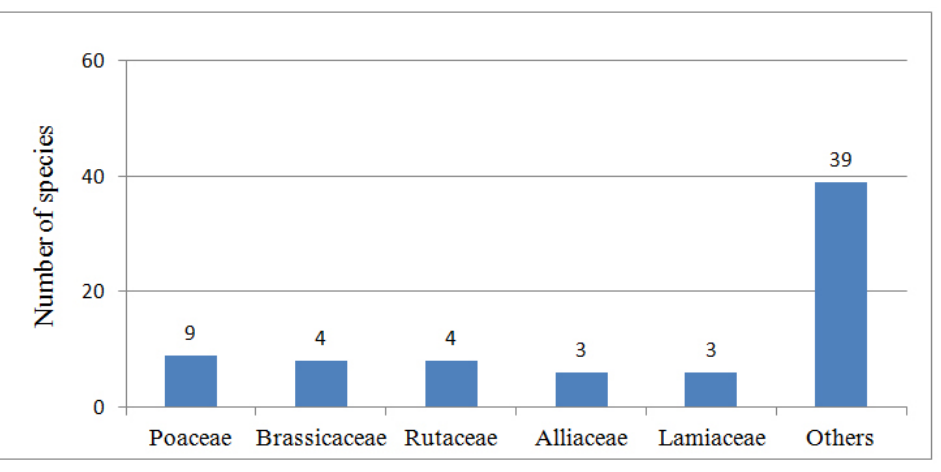

Figure 4. Number of plant species per family in the study area

The use of homegardens by the people of Misha district is customary due to shortage of extensive agricultural lands for cereal crop production and cultural background. Similar to this study, many researches have been conducted on homegarden in this region previously. For example, in his study in Sidama Tesfaye [23] reported a total 120 homegarden plant species.

Table 2. List of plant species in the homegardens of Misha district

\begin{tabular}{|c|c|c|c|c|c|c|}
\hline \multirow{2}{*}{ Scientific name } & \multirow{2}{*}{ Family name } & \multicolumn{2}{|c|}{ local name } & \multirow{2}{*}{ Habit } & \multirow{2}{*}{ Use Value } & \multirow{2}{*}{$\begin{array}{l}\text { Cultivation } \\
\text { management }\end{array}$} \\
\hline & & Amaharic & Hadiyissa & & & \\
\hline Allium porrum. & Alliaceae & shinkurut & shinkuruta & $\mathrm{H}$ & Edible & digging \\
\hline Allium cepa L. & Alliaceae & key shinkurt & shinkuruta & $\mathrm{H}$ & Edible & transplanting \\
\hline Allium sativum L. & Alliaceae & nech shikurt & Tumma & $\mathrm{H}$ & edible, medicinal & Bulb planting \\
\hline Arundo donax L. & Poaceae & shembeko & shombeko & $\mathrm{H}$ & con, life fence & digging \\
\hline Beta vulgaris L. & Chenopodiaceae & key sir & Keysirra & $\mathrm{H}$ & Edible & transplanting \\
\hline Brassica carinata A. Br. & Brassicaceae & gomen & fisho & $\mathrm{H}$ & Edible & transplanting \\
\hline Brassica oleracea L. & Brassicaceae & tikilgomen & shanna & $\mathrm{H}$ & Edible & digging \\
\hline Brassica rapa L. & Brassicaceae & kosta & & $\mathrm{H}$ & Edible & transplanting \\
\hline Canavalia ensiformis (L.) DC. & Fabaceae & boloke & bollokke & $\mathrm{C}$ & Edible & sowing \\
\hline Capsicum annuum L. & Solanaceae & kariya & Mitito’o & $\mathrm{H}$ & Edible & transplanting \\
\hline Carica papaya L. & Caricaceae & papaye & pappayya & $\mathrm{H}$ & edible, medicinal & transplanting \\
\hline Casimiroa edulis La Liave & Rutaceae & kazmir & kasmirras & $\mathrm{T}$ & Edible & Transplanting \\
\hline $\begin{array}{l}\text { Catha edulis (Vahl.) Forssk. } \\
\text { ex Endl. }\end{array}$ & Celastraceae & kchat & chatta & $\mathrm{S}$ & $\begin{array}{l}\text { Stimulant, cash } \\
\text { rop }\end{array}$ & Digging \\
\hline $\begin{array}{l}\text { Citrus aurantifolia (Christm.) } \\
\text { Swingle }\end{array}$ & Rutaceae & lomi & Lomme'e & $\mathrm{S}$ & Edible, medicinal & transplanting \\
\hline
\end{tabular}




\begin{tabular}{|c|c|c|c|c|c|c|}
\hline Citrus sinensis (L.) Osb. & Rutaceae & burtukan & burtukanna & $\mathrm{S}$ & Edible & transplanting \\
\hline Coffea arabica L. & Rubiaceae & buna & bunna & $\mathrm{S}$ & $\begin{array}{l}\text { stimulant,cash } \\
\text { crop, hbf }\end{array}$ & transplanting \\
\hline $\begin{array}{l}\text { Collocasia esculenta (L.) } \\
\text { Schott. }\end{array}$ & Araceae & godare & gaabijja & $\mathrm{H}$ & Edible & digging \\
\hline Cordia africana Lam. & Boraginaceae & wanza & Odda & $\mathrm{T}$ & $\begin{array}{l}\text { con, shade, } \\
\text { furniture, hbf }\end{array}$ & transplanting \\
\hline Coriandrum sativum L. & Apiaceae & dimbilal & dimbillalla & $\mathrm{H}$ & Edible, medicinal & sowing \\
\hline Croton macrostachyus Del. & Euphorbiaceae & bisana & massanna & $\mathrm{T}$ & $\begin{array}{l}\text { con, shade, } \\
\text { furniture, life } \\
\text { fence, medicinal }\end{array}$ & transplanting \\
\hline Cucurbita pepo L. & Cucurbitaceae & duba & dabbakula & $\mathrm{H}$ & Edible, medicinal & sowing \\
\hline Cupresus lusitanica Mill. & Cupressaceae & Yeferenjtid & homma & $\mathrm{T}$ & $\begin{array}{l}\text { con, shade, } \\
\text { furniture, life } \\
\text { fence, cash crop }\end{array}$ & transplanting \\
\hline $\begin{array}{l}\text { Cymbopogon citrates (DC.) } \\
\text { Stapf }\end{array}$ & Poaceae & tej sar & Hite'e & $\mathrm{H}$ & Fodder, medicinal & digging \\
\hline Cynodon dactylon (L.)Pers & Poaceae & serdo & sadda & $\mathrm{H}$ & Fodder & \\
\hline Daucus carota L. & Apiaceae & carot & karrotta & $\mathrm{H}$ & Edible & transplanting \\
\hline Dioscorea praehensilis Benth. & Dioscoreaceae & & kotino & $\mathrm{C}$ & Edible & digging \\
\hline $\begin{array}{l}\text { Ensete ventricosum (Welw.) } \\
\text { Cheesman }\end{array}$ & Musaceae & enset & wessa & $\mathrm{H}$ & $\begin{array}{l}\text { Medicinal edible, } \\
\text { con fodder, fiber }\end{array}$ & Digging \\
\hline Eragrostis tef (Zucc.) & Poaceae & tef & Xaffe'e & $\mathrm{H}$ & Edible, fodder & Sowing \\
\hline Erythrina brucei Schweinf & Fabaceae & korch & Worra,a & $\mathrm{T}$ & Life fence, fuel & Digging \\
\hline $\begin{array}{l}\text { Eucalyptus camaldulensis } \\
\text { Dehnh. }\end{array}$ & Myrtaceae & $\begin{array}{l}\text { Key } \\
\text { Bahir zaf }\end{array}$ & $\begin{array}{l}\text { Kashar } \\
\text { barzaffa }\end{array}$ & $\mathrm{T}$ & $\begin{array}{l}\text { con, life fence, } \\
\text { fuel }\end{array}$ & transplanting \\
\hline Eucalyptus globulus Labill. & Myrtaceae & $\begin{array}{l}\text { Nech bahir } \\
\text { zaf }\end{array}$ & $\begin{array}{l}\text { Qaddal } \\
\text { arzaffa }\end{array}$ & $\mathrm{T}$ & $\begin{array}{l}\text { con, fuel, } \\
\text { furniture, life } \\
\text { fence, cash rop }\end{array}$ & transplanting \\
\hline Grevillea robusta R. Br. & Proteaceae & gravlia & & $\mathrm{T}$ & $\begin{array}{l}\text { Con, shade, } \\
\text { ornamental }\end{array}$ & transplanting \\
\hline $\begin{array}{l}\text { Hagenia abyssinica (Bruce) J. } \\
\text { F. Gmel. }\end{array}$ & Rosaceae & koso & suxxo & $\mathrm{T}$ & $\begin{array}{l}\text { medicinal, con, } \\
\text { shade, furniture, } \\
\text { life fence }\end{array}$ & transplanting \\
\hline Helianthus annuus L. & Asteraceae & suf & suffa & $\mathrm{H}$ & Edible & sowing \\
\hline Hordeum vulgare L. & Poaceae & gebs & So’o & $\mathrm{H}$ & Edible, fodder & sowing \\
\hline Ipomoea batatas (L.) Lam. & Convolvulaceae & $\begin{array}{l}\text { Sikuwar } \\
\text { dinich }\end{array}$ & sukkardinicho & $\mathrm{H}$ & Edible & digging \\
\hline $\begin{array}{l}\text { Juniperus procera Hochst. } \\
\text { ex Endl. }\end{array}$ & Cupressaceae & Yehabeshatid & homma & $\mathrm{T}$ & $\begin{array}{l}\text { con, shade, } \\
\text { furniture, life } \\
\text { fence }\end{array}$ & transplanting \\
\hline $\begin{array}{l}\text { Lippia adoensis var koseret } \\
\text { Sebsebe }\end{array}$ & Verbenaceae & koseret & kosseretta & $\mathrm{S}$ & fragrant & transplanting \\
\hline $\begin{array}{l}\text { Lycopersicon esculentum } \\
\text { Mill. }\end{array}$ & Solanaceae & timatim & timmatima & $\mathrm{H}$ & Edible & transplanting \\
\hline Malus sylvestris Mill. & Rosaceae & aple & & $\mathrm{S}$ & Edible & transplanting \\
\hline
\end{tabular}




\begin{tabular}{|c|c|c|c|c|c|c|}
\hline Mangifera indica L & Anacardiaceae & mango & & $\mathrm{T}$ & Edible & transplanting \\
\hline Musa x paradisiacal L. & Musaceae & muz & & $\mathrm{H}$ & Edible & digging \\
\hline Nicotiana tabacum L. & Solanaceae & tumbaho & kosho & $\mathrm{S}$ & medicinal, & transplanting \\
\hline Ocimum basilicum L. & Lamiaceae & besobila & gemmenja & $\mathrm{H}$ & Edible & transplanting \\
\hline Ocimum lamiifolium $\mathrm{H}$ & Lamiaceae & damakese & minnantofa & $\mathrm{S}$ & medicinal & transplanting \\
\hline $\begin{array}{l}\text { Olea europaea L. subsp. } \\
\text { cuspidata }\end{array}$ & Oliaceae & woyra & werra & $\mathrm{T}$ & $\begin{array}{l}\text { con, life fence, } \\
\text { shade, teeth brush }\end{array}$ & transplanting \\
\hline $\begin{array}{l}\text { Pennisetum violaceum (Lam.) } \\
\text { L. Rich. }\end{array}$ & Poaceae & zihone sar & hitta & $\mathrm{H}$ & fodder & digging \\
\hline Persea americana Mill. & Rutaceae & abokado & Abokkado'o & $\mathrm{T}$ & Edible, shade & transplanting \\
\hline Phaseolus vulgaris L. & Fabaceae & adenguware & & $\mathrm{C}$ & Edible, life fence & sowing \\
\hline $\begin{array}{l}\text { Podocarpus falcatus (Thunb.) } \\
\text { R. B. ex Mirb. }\end{array}$ & Podocarpaceae & zigiba & digibba & $\mathrm{T}$ & $\begin{array}{l}\text { shade, con, } \\
\text { furniture }\end{array}$ & transplanting \\
\hline Prunus persica (L.) Batsch & Rosaceae & kok & kokka & $\mathrm{T}$ & Medicinal, edible & transplanting \\
\hline Rhamnus prinoides L 'Herit. & Rhamnaceae & gesho & gesho & $\mathrm{S}$ & Edible & transplanting \\
\hline Rosa x richardii Rehd. & Rosaceae & tsigereda & ababba & $\mathrm{H}$ & ornamental & digging \\
\hline Rosmarinus officinalis L. & Lamiaceae & Siga etbesha & & $\mathrm{H}$ & Edible & digging \\
\hline Ruta chalepensis L. & Rutaceae & tenadam & carrotta & $\mathrm{H}$ & Medicinal & transplanting \\
\hline Saccharum officinarum L. & Poaceae & $\begin{array}{l}\text { Shenkora } \\
\text { ageda }\end{array}$ & shenkora & $\mathrm{H}$ & Edible & digging \\
\hline Sorghum bicolor (L.) Moench & Poaceae & mashila & sarratta & $\mathrm{H}$ & Edible, fodder & sowing \\
\hline Triticum aestivum L. & Poaceae & sinde & arrasa & $\mathrm{H}$ & Edible & sowing \\
\hline Vicia faba $L$. & Fabaceae & bakela & bakella & $\mathrm{H}$ & Edible & sowing \\
\hline Vitis vinifera $L$. & Vitaceae & woyn & & $\mathrm{C}$ & Edible & transplanting \\
\hline Zea mays L. & Poaceae & bekolo & bokolla & $\mathrm{H}$ & Edible, fodder & sowing \\
\hline Zingiber officinale Roscoe. & Zingiberaceae & zingibil & janjibilla & $\mathrm{H}$ & Edible & Digging \\
\hline
\end{tabular}

$\mathrm{C}=$ climber, $\mathrm{H}=$ herb, $\mathrm{S}=$ shrub, $\mathrm{T}=$ tree, $\mathrm{hbf}=$ =honey bee forage, con=construction

In the study area the richest homegarden contained 25 species, whereas the poorest homegarden contained 9 species. On average, 17 species were recorded from the 60 surveyed homegardens of Misha district. Similar results have been reported by different researchers from different parts of the region and Oromia, Ethiopia. For example, Tesfaye et al. [24] reported 78 cultivated crops from 44 homegardens in Sidama southern Ethiopia with average of 16 spp per homegarden. Mekonnen et al. [4] reported 112 plant species in the home gardens of Holeta town with the mean of 22 species per home garden.

Among the recorded plant species, Ensete ventricosum, Coffea arabica and Brassica carinata were frequently found in homegardens of Misha district, but Zingiber officinale was found only in one homegarden because the climate of the study area is not favorable for this plant. Whereas, (Kola or below $1500 \mathrm{~m}$ asl) is the suitable climatic condition for Z. officinale. The majority of the plant species in the study area were used as sources of food.

Habit wise, home garden species were in the order of herbs (34 spp)>trees (15 spp)>shrubs (9 spp)>climbers (4 spp) (Figure 5). Home gardens of the study area were structured into upper, middle and lower vertical strata. The upper stratum mainly consists of long trees such as Cordia africana, Croton macrostachyus, Juniperus procera, Eucalyptus camaldulensis, Eucalyptus globulus, fruit trees such as Persea americana, Mangifera indica, and Casimiroa edulis. 
The middle stratum consists of Enset ventricosum, Coffea arabica, Catha edulis and Zea mays while vegetables such Beta vulgaris, Brassica carinata, and Capsicum frutescens spices (e.g., Coriandrum sativum) and medicinal plants (e.g., Ruta chalepensis) cover the lower stratum. Similarly, the three strata of homegarden were reported in other parts of the region by [23] in coffee-enset-based Sidama homegardens and by Talemos [25] in enset-based homegardens of Welayta.

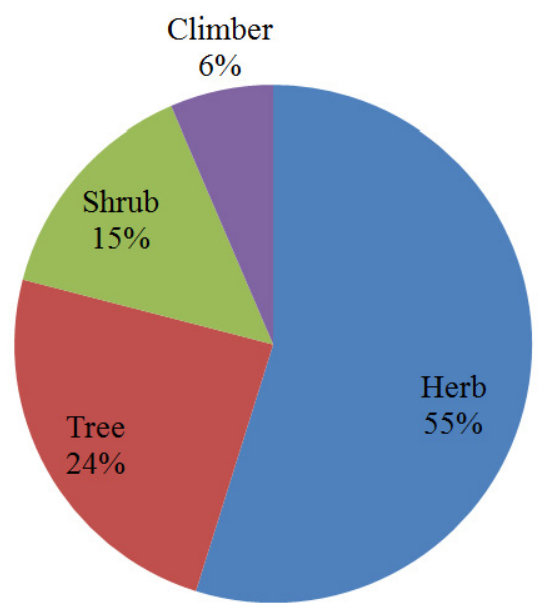

Figure 5. Composition of different plant growth forms (habits) in the home gardens of the study area

\subsection{Homegarden Plant species diversity and richness in Misha district}

In this study, the surveyed kebeles fall in different altitudinal range. Tinika kebele is in the range of 2600-2700 masl, Gidasha 2100-2460, Ololicho 1700-2000 and Forkose 1500-1800 m asl (Table 3). Analysis of variance showed that there was significant difference $(\mathrm{p}<0.05)(\mathrm{p}=0.023)$ between the four kebeles in species richness. Tinika kebele with the highest altitude had the highest number of species compared to the rest of kebeles, which fall below $2500 \mathrm{~m}$ asl (Table 3). However, there was no significant difference between those kebeles that fall below $2500 \mathrm{~m}$ asl in species number, though the numbers appear to decrease with decreasing altitude.

Table 3. Species richness, Shannon-Wiener Diversity Index and Evenness for the study sites

\begin{tabular}{|l|l|l|l|l|}
\hline Study kebeles & Species richness & Shannon's index(H') & Evenness (E) & Altitude \\
\hline Tinika & 50 & 2.42 & 0.22 & $2600-2700 \mathrm{~m}$ \\
\hline Gidasha & 34 & 1.84 & 0.18 & $2100-2460 \mathrm{~m}$ \\
\hline Ololicho & 33 & 2.60 & 0.41 & $1700-2000 \mathrm{~m}$ \\
\hline Forkose & 32 & 2.65 & 0.44 & $1500-1800 \mathrm{~m}$ \\
\hline
\end{tabular}

Likewise, comparison of Shannon-Weiner diversity index showed that there was significant difference $(\mathrm{P}<0.05)$ between kebeles located at different altitudes. In this regard, Forkose kebele, which is located at the lowest altitudinal range had the highest $\mathrm{H}^{\prime}$ value followed by Ololicho and Tinika kebeles. The lowest $\mathrm{H}^{\prime}$ value was for Gidasha kebele. The H' values were not in the same pattern with species richness that revealed a rise in species number with increasing altitude. The fact that Forkose kebele with lowest altitudinal range and lowest species number had the highest $H^{\prime}$ value may suggest that people of this kebele give equal emphasis to all of the species they cultivate. However, People of Gidasha kebele show preference to few species (for example, E. ventricosum) over the others so that such species are found in relatively higher number.

This result is also supported by density data that showed the density value of Ensete ventricosum significantly varied between kebeles (Table 5). Apart from personal preference to cultivate one plant over the other, it is also possible that variation in species richness and diversity between kebeles is due to size of homegarden (annuals and biennials of different species were cultivated in small sized homegardens), socio-economic background (the poor cultivated edible plants than income generating types), altitude that modifies climatic conditions, soil fertility status, proximity to market and road, and cultural and religious factors (did not allow to grow some stimulants plants such as tobacco, kchat, etc). In addition to the above mentioned factors, Mathewos, et al. [19] reported that rainfall pattern, distance from house (highly diversified plants were observed near the house) and management systems affects the diversity of plants in the homegarden of Dawro. 
Comparison of plant species richness and diversity by season revealed significant variation between dry and rainy seasons (Table 4). The Independent-sample T-test showed that there is a significant difference $(\mathrm{P}<0.05)$ of species richness and diversity between seasons in studied kebeles. Enset, coffee, kchat and fruits and other trees found in both dry and rainy seasons, however out of the identified plant species there are some plant species that are available in rainy season, but not in dry season, such as A. cepa, A. sativum, B. vulgaris, B. oleracea, B. rapa, C. ensiformis, C. esculenta, C. sativum, C. pepo, D. carota, D. praehensilis, H. annuus, H. vulgare, I. batatas, O. basilicum, S. bicolor, T. aestivum, V. faba, V. vinifera and Z. mays. Similar results have been reported in other parts of the region by Tesfaye [23] in coffee-enset-based Sidama homegardens that perennial crops, enset and coffee with a life cycle of 6-8 and 24-30 years, respectively while herbaceous crops such as cereals and vegetables are grown only during the rainy period of 6 to 9 months.

Table 4. Plant species richness, diversity and evenness between dry and rainy season in the study area

\begin{tabular}{|l|l|l|l|l|l|l|}
\hline \multirow{2}{*}{ Kebeles } & \multicolumn{3}{|c|}{ Dry season } & \multicolumn{3}{c|}{ Rainy season } \\
\cline { 2 - 7 } & $\begin{array}{l}\text { Species } \\
\text { richness }\end{array}$ & $\begin{array}{l}\text { Shannon's index } \\
\left(H^{\prime}\right)\end{array}$ & Evenness & $\begin{array}{l}\text { Species } \\
\text { richness }\end{array}$ & $\begin{array}{l}\text { Shannon's index } \\
\left(H^{\prime}\right)^{\prime}\end{array}$ & Evenness \\
\hline Tinika & 33 & 1.72 & 0.24 & 50 & 2.42 & 0.22 \\
\hline Gidasha & 25 & 1.61 & 0.19 & 34 & 1.84 & 0.18 \\
\hline Ololicho & 24 & 2.28 & 0.4 & 33 & 2.6 & 0.41 \\
\hline Forkose & 24 & 2.35 & 0.43 & 32 & 2.65 & 0.44 \\
\hline P-value & $0.007 *$ & $0.01 *$ & & & & \\
\hline
\end{tabular}

\subsection{Density and Frequency of Homegarden Plant Species}

The people in the study area cultivate different plant species in their homegardens, which provide a number of functions. The overall density and frequency of plant species was computed and the results of species with high values are indicated in (Table 5). Accordingly, of the 62 plant species identified in the study area, E. ventricosum was found to have high density followed by D. carota. Similarly the frequency of E. ventricosum followed by C. arabica, Z. mays and B. carinata was the highest compared to the rest of plant species, also C. africana has highest value of frequency in Forkose and Ololicho over the rest kebeles (Table 5). This suggests that E. ventricosum is the dominant plant species in the homegardening activities of the study area. Plant species with the high density and frequency are found to be the ones used for food, timber production and income generation.

Table 5. Plant species with highest density and frequency value in the study area

\begin{tabular}{|l|l|l|l|l|l|l|l|l|}
\hline \multirow{2}{*}{ Scientific name } & \multicolumn{3}{|l}{ Value of density } & \multicolumn{3}{l|}{ Value of frequency (\%) } \\
\cline { 2 - 9 } & Tinika & Gidasha & Ololicho & Forkose & Tinika & Gidasha & Ololicho & Forkose \\
\hline E.ventricosum & 0.323 & 0.302 & 0.113 & 0.047 & 91.1 & 86.6 & 71.2 & 66.8 \\
\hline D. carota & 0.112 & 0.111 & 0.101 & 0.011 & 8.8 & 8.8 & 2.3 & 3.3 \\
\hline B. carinata & 0.037 & 0.028 & 0.024 & 0.007 & 44.4 & 37.7 & 31.1 & 22.2 \\
\hline Z. mays & 0.034 & 0.039 & 0.042 & 0.046 & 44.4 & 51.1 & 57.7 & 64.4 \\
\hline A. porrum & 0.034 & 0.012 & & 0.002 & 28.8 & 15.5 & & 11.1 \\
\hline B. vulgaris & 0.022 & 0.004 & 0.024 & & 17.7 & 13.3 & 12.1 & \\
\hline C. arabica & 0.017 & 0.011 & 0.046 & 0.046 & 35.5 & 42.5 & 82.2 & 86.6 \\
\hline C. frutescens & 0.017 & 0.008 & 0.011 & 0.003 & 20 & 15.5 & 28.8 & 6.6 \\
\hline S. officinarum & 0.011 & 0.012 & 0.011 & 0.005 & 24.4 & 20 & 20 & 46.6 \\
\hline P. americana & 0.006 & 0.007 & 0.013 & 0.014 & 40 & 46.6 & 60 & 64.4 \\
\hline C.edulis & 0.005 & 0.004 & 0.016 & 0.021 & 13.3 & 13.3 & 20 & 17.7 \\
\hline P. vulgaris & 0.004 & 0.005 & 0.013 & 0.006 & 26.6 & 28.8 & 48.8 & 17.7 \\
\hline M. paradisiaca & 0.0004 & 0.001 & 0.015 & 0.014 & 4.2 & 5.6 & 40 & 17.7 \\
\hline C. africa & 0.0002 & 0.002 & 0.018 & 0.012 & 13.3 & 15.5 & 68.8 & 71.1 \\
\hline
\end{tabular}

Missing data in the above table indicates A. porrum in Ololicho and B. vulgaris in Forkose were not recorded. 


$$
\text { Density }=\frac{\text { Number of individuals in the sample }}{\text { Total area of the sample }\left(\mathrm{m}^{2}\right)}
$$

\subsection{Use of Homegarden Plant Species in Misha District}

Homegardens maintain the diverse mixtures of plants that will be harvested at different times for food and other purposes. Homegarden plant species of the study area were grouped into seven major use categories (Figure 6). Most of these plant species have multiple uses. Relatively higher numbers of the plants ( 25 species) were used as source of food followed by medicine, construction, live-fence, fodder and ornamental purposes. Enset ventricosum, Colocosia esculenta, Zea mays, Phaseolus vulgaris, Vicia faba, Cucurbita pepo, Beta vulgaris, Daucus carota and Brassica spp. are the widely cultivated plants for human food.

Some of the medicinal plant species occurred in the homegardens of the study area are Carica papaya, Ocimum lamiifolium, Ruta chalepensis, and Croton macrostachyus. On the other hand, some of the plant species that are used for construction are Eucalyptu globulus, Cupresus lusitanica, Cordia africana, Arundo donax, Eucalyptus camaldulensis, Grevillea robusta, Hagenia abyssinica, Juniperus procera, Podocarpus falcatus, but Croton macrostachyus, Hagenia abyssinica Cupresus lusitanica and Phaseolus vulgaris are used as live-fence. Additionally Enset ventricosum, Hordeum vulgare, Cynodon dactylon, Pennisetum violaceum, Triticum aestivum, and Zea mays are of some plants species used for fodder whereas Rosa x richardii is one of the important ornamental plant species in the study area. Zemede [26] reported about 126 (75\% of the total record) plant species used as food from Ethiopian homegardens. Moreover, Belachew et al [27] reported 48 edible plant species from homegardens of Arbaminch areas. Solomon [28] identified about 68 plant species used as food from homegarden areas in Kochere Wereda. Feleke [29] and Mathewos et al [19] reported 102 and 77 food plants from homegardens of Basketo and Dwaro zone, respectively.

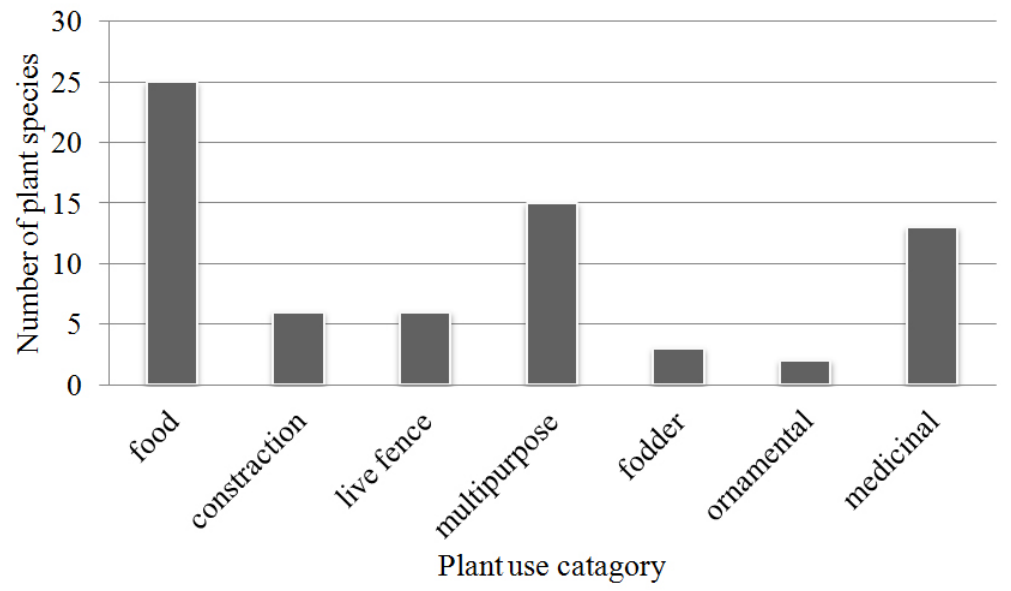

Figure 6. General uses of homegarden plant species in the study area

\section{Summary and Conclusion}

This study was conducted with the objective of identifying homegarden plant species; determine plant species richness and diversity for comparison between kebeles of different altitude in Misha District. Data were gathered through semi-structured interview and field visit in the study area. A total of 60 households from 4 kebeles were sampled for the study. Results of the study showed that people of the study area practice homegardening with minimum and maximum honegarden sizes of 0.1 and 1 ha. A total of 62 plant species distributed in 35 families were documented in the study area. These plants were categorized into 7 use categories with most of them having multi-use and considerable numbers for food value and medicinal purpose.

The management of multi-species agro-system for fulfilling the subsistence and cash needs of households enhances homegarden sustainability. However, socio-economic status, soil fertility, garden size, cultural and personal preferences and variation of seasons have their own influence on plant diversity in the homegardens of study area. Therefore Proper management of homegardens plant species has a great potential for biodiversity conservation, improving food security and provides contribution for ecosystem services in the homegarden. On other hand diversity and richness of the homegarden plant species are significantly different $(\mathrm{P}<0.05)$ in kebeles over the study area between rainy and dry seasons, this shows that higher plant species diversity was observed in rainy season. Therefore it is possible to increase plant species diversity in dry season by developing awareness of using irrigation among the gardeners.

Based on the research results, the following recommendations are forwarded: 
- Encourage home gardening for plant biodiversity conservation and management as well as for ecological interventions (for cultivation of spices, medicinal plants and other multipurpose species);

- Suitable subsistence and cash crops for improving homegarden productivity without destroying its structure and functioning should be identified and promoted. Gardeners should be integrated as an active part in the whole process of developing a holistic approach for raising and maintaining the sustainability of homegardens together with conserving its agrobiodiversity.

\section{Acknowledgement}

The authors would like to thank Mr. Tarekegn Kalbago, Mr. Feleke Ergando and Mr. Lamesgn Wolde.

\section{References}

[1] Gebreegziabher, Z., Stage, J., Mekonnen, A., \& Alemu, A. (2011). Climate change and the Ethiopian economy: A computable general equilibrium analysis.

[2] Di Falco, S., Yesuf, M., Kohlin, G., \& Ringler, C. (2012). Estimating the impact of climate change on agriculture in lowincome countries: Household level evidence from the Nile Basin, Ethiopia. Environmental and Resource Economics, 52(4), 457-478.

[3] Eriksen, S. H., Brown, K., \& Kelly, P. M. (2005). The dynamics of vulnerability: locating coping strategies in Kenya and Tanzania. Geographical Journal, 171(4), 287-305.

[4] Amberber, M., Argaw, M., \& Asfaw, Z. (2014). The role of homegardens for in situ conservation of plant biodiversity in Holeta Town, Oromia National Regional State, Ethiopia. International Journal of Biodiversity and Conservation, 6(1), 8-16.

[5] McNeely, J. A., \& Schroth, G. (2006). Agroforestry and biodiversity conservation-traditional practices, present dynamics, and lessons for the future. Biodiversity \& Conservation, 15(2), 549-554.

[6] Michon, G., Bompard, J., Hecketsweiler, P., \& Ducatillion, C. (1983). Tropical forest architectural analysis as applied to agroforests in the humid tropics: the example of traditional village-agroforests in West Java. Agroforestry Systems, 1(2), 117-129.

[7] Fernandes, E. C., \& Nair, P. R. (1986). An evaluation of the structure and function of tropical homegardens. Agricultural systems, 21(4), 279-310.

[8] Soemarwoto, O. (1987). Homegardens: a traditional agroforestry system with a promising future. Agroforestry: A decade of development, 157-170.

[9] Udofia, S. I., Owoh, P. W., Ukpong, E. E., \& Ekpo, I. E. (2012). Assessment of plant species of socio economic importance conserved in homegardens of Nsit Ubium local government area of Akwa Ibom State, Nigeria. Nigerian Journal of Agriculture, Food and Environment, 8(1), 99-108.

[10] Fernandes, ECM., \& Nair, PKR.(1990). An evaluation of the structure and function of tropical Homegardens. pp. 105114. In: Landauer, K.and Brazil, M. (eds.), Tropical Home Gardens. Tokyo: united Nations University Press.

[11] Sahoo, U. K. (2009). Traditional home gardens and livelihood security in North-East India. J Food Agric Environ, 7, $665-670$.

[12] Verchot, L. V., Van Noordwijk, M., Kandji, S., Tomich, T., Ong, C., Albrecht, A., Mackensen, J., bantilan, C., Anupama, KV. \& Palm, C. (2007). Climate change: linking adaptation and mitigation through agroforestry. Mitigation and adaptation strategies for global change, 12(5), 901-918.

[13] Brandt, S. A. (1997). The'Tree against hunger'Ensete-Based Agricultural Systems in Ethiopia. In American Association for the advancement of science (Vol. 55).

[14] Masayoshi, S. H. I. G. E. T. A. (1989). Folk In-Situ Conservation of Ensete [Ensete ventricosum (Welw.) EE Cheesman]: Toward the Interpretation of Indigenous Agricultural Science of the Ari, Sowthwestern Ethiopia. African study monographs, 10(3), 93-107.

[15] Welde-Michael, G., Bobosha, K., Blomme, G., Addis, T., Mengesha, T., \& Mekonnen, S. (2008). Evaluation of enset clones against enset bacterial wilt. African Crop Science Journal, 16(1).

[16] FDRE, P., \& Federal Democratic Republic of Ethiopia Population Census Commission. (2008). Summary and statistical report of the 2007 population and housing census: Population size by age and sex. Addis Ababa: Population Census Policy.

[17] SNNPRBOARD (Southern Nations Nationalities and Peoples Region Bureau of Agriculture and Rural Development). (2007). Annual Report of Agriculture and Rural Development Bureau, Southern Nations Nationalities and Peoples Region, Hawassa, Ethiopia.

[18] Shannon, C.E., \& Wiener, W. (1949). The mathematical theory of communication. The University of Illinois Press. 
[19] Mathewos, A., Sebsebe, D., \& Zemede, A. (2013). Indigenous Knowledge on Management Of Home Gardens And Plants In Loma And Gena Bosa Districts (Weredas) Of Dawro Zone, Southern Ethiopia: Plant Biodiversity Conservation, Sustainable Utilization And Environmental Protection. International Journal of Sciences: Basic and Applied Research, $10,63-99$.

[20] Zemede, A., \& Ayele, N. (1995). Home-gardens in Ethiopia: characteristics and plant diversity. SINET, an Ethiopian Journal of Science, 18(2), 235-266.

[21] Mengistu, F. (2008). Fruit tree species in the wild and in home garden agroforestry: species composition, diversity and utilization in western Amhara region, Ethiopia (Doctoral dissertation, $\mathrm{PhD}$ thesis, BOKU, Vienna).

[22] Seta, T., Demissew, S., \& Asfaw, Z. (2013). Home gardens of Wolayta, Southern Ethiopia: an ethnobotanical profile. Academia J. Medicinal Plants, 1, 14-30.

[23] Abebe, T. (2005). Diversity in homegarden agroforestry systems of Southern Ethiopia.

[24] Abebe, T., Wiersum, K. F., \& Bongers, F. (2010). Spatial and temporal variation in crop diversity in agroforestry homegardens of southern Ethiopia. Agroforestry systems, 78(3), 309-322.

[25] Talemos, S. (2007). Diversity in Enset-Based Home-Gardens and Its Significance to Household Supply in Wolayta (Southern Ethiopia): An Ethnobotanic Approach. M Sc (Ag) thesis, Addis Ababa University, Ethiopia, 105p.

[26] Zemede, A. (1997). Survey of indigenous food plants, their preparations and home gardens in Ethiopia. Indigenous African food crops and useful plants (Bede N, Okigbo BN eds.) ICIPE Science Press, Nairobi, 65.

[27] Wassihun, B., Asfaw, Z., \& Demissew, S. (2003). Ethnobotanical study of useful plants in daniio gade (home-gardens) in Southern Ethiopia. Ethiopian journal of Biological Sciences, 2, 119-141.

[28] Tamrat, S. (2011). Study of useful plants in and around Gate Uduma (Traditional Gedeo Homegardens Gardens) in Kochere Wereda of Gedeo zone, SNNPR, Ethiopia: An ethnobotanical approach (Doctoral dissertation, MSc Thesis).

[29] Woldeyes, F. (2011). Homegardens and spices of Basketo and Kafa (Southwest Ethiopia): Plant diversity, product valorization and implications to biodiversity conservation (Doctoral dissertation, $\mathrm{PhD}$ thesis. Addis Ababa University, Ethiopia). 